\title{
TRANSACTIONS
}

\section{of FAMENA}

\section{Contents}

Comparison of Finned Tube and Plate-Finned Heat Exchangers in Waste Heat Recovery

Mario Holik, Marija Živić, Zdravko Virag, Antun Barac

Local Entropy Production of the Parallel Flow and Counterflow Heat Exchanger

Martina Rauch, Antun Galović, Nenad Ferdelji, Saša Mudrinić

Study of Operative Temperature Using the Novel Detail Approach in Determining Mean Radiant Temperature - Comparison Between Wall-Mounted Convector and Conventional Radiator

Jura Tomorad, Ivan Horvat, Damir Dović

Ground Thermal Response and Recovery after Heat Injection:

Experimental Investigation

Luka Boban, Vladimir Soldo, Jure Stošić, Eugen Filipović, Filip Tremac

Yield and Biomass Composition of Miscanthus $x$ Giganteus in the Mountain Area of Croatia

Nikola Bilandžija, Neven Voća, Josip Leto, Vanja Jurišić,

Mateja Grubor, Ana Matin, Anja Geršić, Tajana Krička.

Estimate of Heat Transfer Coefficient during Quenching Steel in Water

Šefik Behrem, Bahrudin Hrnjica

Combustion of Agricultural Biomass - Issues and Solutions

Ivan Horvat, Damir Dović

Cable Aging Monitoring with Differential Scanning Calorimetry (DSC) in Nuclear Power Plants

Marko Pirc, Jurij Avsec, Nataša Čelan Korošin,

Urška Lavrenčič Štangar, Romana Cerc Korošec 
Regarding the English language, no corrections have been made and the papers are printed as received from the authors and the organizers of the symposium.

Editor-in-Chief 